NBER WORKING PAPER SERIES

\title{
OPTIMAL MONETARY POLICY IN CLOSED VERSUS OPEN ECONOMIES: AN INTEGRATED APPROACH
}

\author{
Richard H. Clarida \\ Jordi Gali \\ Mark Gertler
}

Working Paper 8604

http://www.nber.org/papers/w8604

\author{
NATIONAL BUREAU OF ECONOMIC RESEARCH \\ 1050 Massachusetts Avenue \\ Cambridge, MA 02138 \\ November 2001
}

The views expressed herein are those of the authors and not necessarily those of the National Bureau of Economic Research.

(C) 2001 by Richard H. Clarida, Jordi Gali and Mark Gertler. All rights reserved. Short sections of text, not to exceed two paragraphs, may be quoted without explicit permission provided that full credit, including $(\mathcal{C}$ notice, is given to the source. 
Optimal Monetary Policy in Closed versus Open Economies:

An Integrated Approach

Richard H. Clarida, Jordi Gali and Mark Gertler

NBER Working Paper No. 8604

November 2001

JEL No. F31

\begin{abstract}
$\underline{\text { ABSTRACT }}$
This paper develops a new open economy macro model of optimal monetary for a small open economy. Our main result is that in this model, the optimal policy problem for the small open economy is isomorphic to the closed economy case studied in Clarida, Gali, Gertler (1999). In particular, the optimal policy can be implemented with a Taylor Rule under which the domestic interest rate adjusts to the equilibrium real interest rate and expected inflation in domestic prices.
\end{abstract}

\author{
Richard Clarida \\ NBER and Columbia University \\ Room 1014 \\ 420 W. 118th Street \\ New York, NY 10027 \\ rhc2@columbia.edu \\ Jordi Gali \\ NBER, CEPR and Universitat Pompeu Fabra \\ 08005 Barcelona Spain \\ Mark Gertler \\ NBER and New York University \\ 269 Mercer Street \\ New York, NY 10003
}




\title{
OPTIMAL MONETARY POLICY IN OPEN VERSUS CLOSED ECONOMIES:
}

\section{AN INTEGRATED APPROACH}

\author{
Richard Clarida, Jordi Gali, and Mark Gertler ${ }^{*}$
}

January 11,2001

In Richard Clarida, Jordi Gali and Mark Gertler ((1999); hereafter CGG), we presented a normative analysis of monetary policy within a simple optimization-based closed economy framework. We derived the optimal policy rule and, among other things, characterized the gains from commitment. Also, we made precise the implications for the kind of instrument feedback rule that a central bank should follow in practice. In this paper we show how our analysis extends to the case of small open economy. Openness complicates the problem of monetary management to the extent the central bank must take into account the impact of the exchange rate on real activity and inflation. How to factor the exchange rate into the overall design of monetary policy accordingly becomes a central consideration.

Here we show that under certain conditions, the monetary policy design problem for the small open economy is isomorphic to the problem of the closed economy that we considered earlier. Hence, all our qualitative results for the closed economy carry over to this case. Openness does affect the parameters of the model, suggesting quantitative implications. Though the general form of the optimal interest rate feedback rule remains the same as in the closed economy case, for example, how aggressively a central bank should adjust the interest rate in response to inflationary pressures depends on the degree of openness. In addition, openness gives rise to an important distinction between domestic inflation and consumer price (cpi) inflation. To the extent there is perfect exchange rate pass through, we find that the central bank should target domestic inflation and allow the exchange rate to float, despite the impact of the resulting exchange variability on the cpi (Kosuki Aoki (1999) and Gali and Tommaso Monacelli (2000)). 


\section{A Small Open Economy Framework}

We consider a small open economy model with money, imperfect competition and nominal price rigidities, similar to Lars Svensson (2000), Maurice Obstfeld and Kenneth Rogoff (2000), Gali and Monacelli (2000) and others. One key difference is that, in addition to having nominal price rigidities in the form of staggered price setting, we allow for a friction in the labor market in order to introduce a short run tradeoff between inflation and output.

Only consumption goods are produced and traded. Households consume a domestic and a foreign good that are imperfect substitutes. The domestic good is a composite of a continuum of differentiated goods, each produced by an associated monopolistically competitive firm at home. The home economy is small in the sense that it does not influence foreign output, the foreign price level or the foreign interest rate; however, the equilibrium terms of trade will depend on both home and foreign disturbances. We abstract from wealth effects due to current account imbalances by allowing households to share consumption risk internationally. To conserve space, we present only the $\log$ linearized version of the model. Accordingly, all variables are expressed as percent deviations from their long run equilibrium levels.

Household consumption, $c_{t}$, is a CES composite of home and foreign goods, given in loglinear form by

$$
c_{t}=(1-\gamma) c_{t}^{h}+\gamma c_{t}^{f}
$$

where the superscripts $\mathrm{h}$ and $\mathrm{f}$ denote home and foreign respectively, and $\gamma$ measures openness . In turn, domestic output, $\mathrm{y}_{\mathrm{t}}$, is divided between goods sold to domestic residents, $\mathrm{c}_{t}^{h}$ and goods sold to foreigners, $\mathrm{c}^{h^{*}}$

$$
y_{t}=(1-\gamma) c_{t}^{h}+\gamma c_{t}^{h^{*}}
$$


The representative household chooses consumption, labor supply, saving and money holding to maximize a discounted stream of utility that depends on the consumption index, leisure and real money balances. The first order conditions (in loglinear form) are given as follows:

$$
\begin{aligned}
& c_{t}^{h}-c_{t}^{f}=\eta s_{t} \\
& w_{t}-p_{t}-\gamma s_{t}=\left(\phi n_{t}+\sigma c_{t}\right)+\mu_{t}^{w} \\
& c_{t}=E_{t} c_{t+1}-\frac{1}{\sigma}\left[r_{t}-E_{t}\left(\pi_{t+1}+\gamma E_{t} \Delta s_{t+1}\right)\right] \\
& E_{t} \Delta s_{t+1}+r_{t}^{*}-E_{t} \pi_{t+1}^{*}=r_{t}-E_{t} \pi_{t+1}
\end{aligned}
$$

Equation (3) relates the household's demand for home versus foreign goods to the terms of trade $s_{t}$, where $\eta$ is elasticity of substitution. We assume further that the law of one price holds, implying that $s_{t}$ $=e_{t}+p_{t}{ }_{t}-p_{t}$, where $e_{t}$ the nominal exchange rate, $p^{*}{ }_{t}$ is the foreign price level and $p_{t}$ is the price of domestic output. Equation (4) is the first order condition for labor supply. The left side is the real wage: the nominal wage, $\mathrm{w}_{\mathrm{t}}$, minus the consumer price level, $p_{t}+\gamma s_{t}$. The first term on the right is the marginal rate of substitution between leisure and consumption, where $\mathrm{n}_{t}$ is employment, $\phi$ is the inverse of the labor supply elasticity and $\sigma$ is the coefficient of relative risk aversion. The second term, $\mu_{t}^{w}$, which we call the "wage markup", reflects frictions in the wage setting that may distort the real wage from its competitive equilibrium value, $\left(\phi n_{t}+\sigma c_{t}\right)$. In general, these frictions may stem from either real rigidities (e.g. efficiency wages) or nominal rigidities (e.g long term nominal contracts ). For simplicity, we take $\mu_{t}^{w}$ as an exogenous stationary first order stochastic process.

Among the complete set of state-contingent claims the household may hold are domestic and foreign one period nominal bonds. Equation (5) is first order condition for consumption versus saving in domestic bonds, where the real return on domestic bonds is the difference between the nominal interest, 
$r_{t,}$ and the expected rate of consumer price inflation, $\mathrm{E}_{\mathrm{t}}\left(\pi_{\mathrm{t}+1}+\gamma \Delta \mathrm{s}_{\mathrm{t}+1}\right)$, given that $\pi_{t+1}=p_{t+1}-p_{t}$ is domestic inflation and $\Delta \mathrm{s}_{\mathrm{t}+1}=\mathrm{s}_{t+1}-\mathrm{s}_{t}$ is the rate of depreciation of the terms of trade. In addition, the option to trade costlessly in foreign bonds implies that, up to linearization, uncovered interest parity will hold, as expressed by equation (6), where $r^{*}$ is the foreign nominal interest rate and $\pi^{*}{ }_{t+1}$ is inflation in the foreign currency price of foreign goods. Finally, as noted, households have access to a complete set of international securities markets to share consumption risk. This assumption together with the assumption that all exogenous shocks are stationary implies that over time the terms of trade reverts to the steady state, as follows

$$
\lim _{i \rightarrow \infty} E_{t} s_{t+i}=0
$$

We assume that consumption by foreigners is also a CES index of home produced and foreign goods. Following Gali and Monacelli (2000), we treat the foreign country as large by assuming that the weight in the foreign CES aggregator on home goods is negligible. Accordingly, for the foreign country, output is equal to domestic consumption and consumer price inflation is equal to domestic inflation. It follows that foreign demand for domestic output depends on foreign output, $\mathrm{y}^{*}{ }_{\mathrm{t}}$, and the terms of trade:

$$
c_{t}^{h^{*}}=y_{t}^{*}+\eta s_{t}
$$

where, for convenience, we assume that the elasticity of substitution, $\eta$, is the same across countries. In addition, we can express the consumption euler equation for foreigners as

$$
r_{t}^{*}-E_{t} \pi_{t+1}^{*}=\sigma E_{t}\left(y_{t+1}^{*}-y_{t}^{*}\right)
$$

Equation (9) links the foreign real interest rate to the growth of foreign output, taken here to be an exogenous stationary process.

The domestic production sector of this small open economy is identical to the closed economy counterpart of this model. In particular, the domestic consumption good is a CES composite of a continuum of goods produced at home. Each firm accordingly faces a demand curve with constant 
relative price elasticity that is homogenous of degree one in total demand for home consumption. Production is linear in labor, the only input, as follows

$$
y_{t}=a_{t}+n_{t}
$$

where $a_{t}$ is an exogenous, stationary stochastic process for home productivity.

We assume that firms set nominal prices on a staggered basis, following Guillermo Calvo (1983).

Firms changing price in the current period choose an optimal price based on the expected path of marginal cost. Firms not changing price simply adjust output to meet demand. Aggregating across firms leads to the following "New Phillips Curve" that, in its primitive form, relates domestic inflation to real marginal cost, $m c_{t}$, and expected future inflation as follows

$$
\pi_{t}=\beta E_{t} \pi_{t+1}+\delta m c_{t}
$$

where, from cost minimization, $m c_{t}$ equals the product wage divided by the marginal product of labor:

$$
m c_{t}=w_{t}-p_{t}-a_{t}
$$

Equations (11) and (12) are identical to their counterparts for the closed economy, except that they pertain strictly to domestic inflation.

\section{The Open Economy Policy Problem}

Let $\mathrm{y}_{t}^{o}$ be the natural level of output, defined as the level of output that arises with perfectly flexible prices and no cyclical distortions in the labor market (i.e., with $\mathrm{mc}_{\mathrm{t}}=0$ and $\mu_{t}^{w}=0$ ). Similarly, let $r r_{t}^{o}$ and $\mathrm{s}_{t}^{o}$ be the domestic real interest rate and the terms of trade, respectively, that arise in the frictionless equilibrium. Finally, let $\mathrm{x}_{\mathrm{t}}=\mathrm{y}_{\mathrm{t}}-\mathrm{y}_{t}^{o}$ be the output gap. It is then possible to collapse the model into a system of three equations that determine $x_{t}, \pi_{t}$, and $s_{t}$ conditional on the path of the nominal interest rate: 


$$
\begin{aligned}
x_{t} & =E_{t} x_{t+1}-\frac{1+w}{\sigma}\left(r_{t}-E_{t} \pi_{t+1}-r r_{t}^{o}\right) \\
\pi_{t} & =\beta E_{t} \pi_{t+1}+\lambda_{w} x_{t}+u_{t} \\
s_{t} & =\frac{\sigma}{1+w} x_{t}+s_{t}^{o}
\end{aligned}
$$

with $w=\gamma(\sigma \eta-1)(2-\gamma), \lambda_{\mathrm{w}}=\delta\left(\frac{\sigma}{1+w}+\phi\right) ; \mathrm{u}_{\mathrm{t}}=\delta \mu_{t}^{w}$, and with

$$
\begin{aligned}
& r r_{t}^{o}=\frac{w}{1+w} r r_{t}^{*}+\frac{\sigma}{1+w} E_{t}\left(y_{t+1}^{o}-y_{t}^{o}\right) \\
& y_{t}^{o}=\frac{(1+\phi) \alpha_{t}-\sigma\left(\frac{w}{1+w}\right) y_{t}^{*}}{[\sigma /(1+w)+\phi]} \\
& s_{t}^{o}=\frac{\sigma}{1+w}\left(y_{t}^{o}-y_{t}^{*}\right) .
\end{aligned}
$$

Equation (13) is essentially an "IS curve" that relates the output gap inversely to the domestic real interest rate and positively to the expected future output gap. As in the closed economy, holding constant the frictionless equilibrium, a rise in the domestic real rate reduces aggregate demand, and hence the current output gap, by inducing intertemporal substitution of consumption. For the open economy, since the rise in the domestic real rate induces an appreciation of the terms of trade, there is also an expenditure switching effect on demand, captured by the influence of the parameter $w$ on the interest sensitivity of $x_{t}$. The expenditure switching effect causes net exports to move in a direction that magnifies the overall impact on demand, if the elasticity of substitution between home and foreign goods, $\eta$, is sufficiently large to satisfy $\sigma \eta>1$ (implying $w>0$ ), as seems reasonable empirically.

Equation (14) is a short run aggregate supply (AS) curve that relates domestic inflation to the output gap and a "cost push shock", $\mathrm{u}_{\mathrm{t}}$. As in CGG, the "cost push shock" reflects determinants of marginal cost that do not move proportionately with the output gap. Here we relate $u_{t}$ explicitly to the 
wage markup, $\mu_{t}^{w}$. (To see, note that marginal cost may be expressed $m c_{t}=\left(\frac{\sigma}{1+w}+\phi\right) x_{t}+\mu_{t}^{w}$, and then compare equations (11) and (14)). As emphasized in CGG, the cost push shock introduces a short run tradeoff between $x_{t}$ and $\pi_{t}$. Finally, equation (15) relates the terms of trade, $s_{t}$, positively to the output gap. As domestic output rise relative to foreign output the terms of trade must depreciate. To clear markets, domestic goods must become cheaper relative to foreign goods.

We next turn to the policy objective. The consideration of the terms of trade makes the objective differ from what is standard for a closed economy (Giancarlo Corsetti and Paolo Pesenti (2000)). However, it follows from equation (15) that the "terms of trade gap", $\mathrm{s}_{\mathrm{t}}-\mathrm{s}_{t}^{o}$ is proportionate to the output gap, $\mathrm{x}_{\mathrm{t}}$. Accordingly, under certain conditions, based on a second order approximation of the household's utility function, it is possible to collapse the policy objective to

$$
\max -(1 / 2) \sum_{i=0}^{i=\infty} E_{t}\left[\alpha_{w} x_{t+i}^{2}+\pi_{t+i}^{2}\right]
$$

where we use equation (15) to fold $\mathrm{s}_{\mathrm{t}}-\mathrm{s}_{t}^{o}$ into $\mathrm{x}_{\mathrm{t}}$. Equation (16) thus takes a standard form for a closed economy (see, e.g., Michael Woodford (1999)): a quadratic loss function in the output gap and inflation, though we emphasize that the latter in this case corresponds to domestic inflation. To derive equation (16), we assume that taxes adjust to counteract the distortions in the economy in a way that eliminates any incentive to create either unanticipated inflation or unanticipated deflation (see Gianluca Benigno and Pierpaolo Benigno (2000)).

The monetary policy problem for the small open economy thus simplifies to choosing a path for the nominal interest rate, $r_{t}$, to minimize the loss (16) subject to the IS and AS equations. As we have foreshadowed, both the IS and AS curves have the same general form as in the closed economy studied by CGG: Indeed, as the parameter which reflects openness, $\gamma$, goes to zero, $w=\gamma(\sigma \eta-1)(2-\gamma)$ 
converges to zero, implying that the coefficients in the IS and AS curves become identical to their closed economy counterparts. Similarly, the objective is of the same general form as for the closed economy. Thus we have,

Result 1: The policy problem for the small open economy studied here is isomorphic to the policy problem for the closed economy in CGG.

It follows that the feedback rule for nominal interest rate $r_{t}$ as well as the time paths for $x_{t}$ and $\pi_{t}$ under the optimal policy are qualitatively the same as in the closed economy case. For the open economy, of course, the optimal policy also has implications for the terms of trade. From equation (15), however, conditional on the path of $\mathrm{x}_{\mathrm{t}}$ under the desired monetary policy and on $s_{t}^{o}$, we obtain an expression for the optimal path of $\mathrm{s}_{\mathrm{t}}$.

\section{Optimal Policy Under Discretion and Under Commitment}

Under discretion, the central bank re-optimizes each period. Under commitment, the central bank chooses a binding state-contingent rule. With forward looking price setting and a short run output inflation tradeoff, as we have here, there are gains from commitment to a rule, as emphasized in CGG, Woodford (1999) and elsewhere. We begin with discretion and then briefly discuss commitment.

Given Result 1, we follow CGG to derive the solution under discretion. In analogy to the closed economy case, the optimum is characterized by a "lean against the wind" policy that has the central bank contract demand as domestic inflation rise above target, as follows,

$$
\mathrm{x}_{\mathrm{t}}=-\left(\lambda_{\mathrm{w}} / \alpha_{\mathrm{w}}\right) \pi_{\mathrm{t}}
$$

The reduced forms for the output gap and domestic inflation, in turn, are given by

$$
\begin{aligned}
& x_{t}=-\lambda_{w} q_{w} u_{t} \\
& \pi_{t}=\alpha_{w} q_{w} u_{t}
\end{aligned}
$$


with $\left.\mathrm{q}_{\mathrm{w}}=1_{\text {[[ }} \lambda_{w}{ }^{2}+\alpha_{w}(1-\beta \rho)\right]$, where $\rho<1$ is the autocorrelation in the cost push shock. In general, a positive cost push shock induces the central bank to contract demand to moderate the impact on domestic inflation. Overall, the policy aims for gradual of convergence of domestic inflation to target (note that the cost push shock is stationary), except in the extreme case where the policy objective places zero weight on the output gap (i.e., $\alpha_{\mathrm{w}}=0$.) An interest rate feedback rule which implements the optimal policy is

$$
r_{t}=r r_{t}^{\circ}+b E_{t} \pi_{t+1}
$$

with $\mathrm{b}=1+[\sigma(1+\omega)]\left(\lambda_{w} / \alpha_{w}\right)(1-\rho) / \rho>1$. The central bank should respond to expected deviations of domestic inflation from target by adjusting the nominal rate sufficiently to have the real rate move in a stabilizing manner. The rule is of the same form as for the closed economy. International factors are relevant to the extent they affect domestic inflation or the equilibrium real rate, $r r^{\circ}{ }_{t}$.

Under the optimal policy, cpi inflation is more volatile than domestic inflation. The monetary tightening that follows a positive cost push shock also induces an appreciation in the terms trade (see equations (15) and (18)), which moderates the initial impact on the cpi. Over time, however, the terms of trade depreciates, causing cpi inflation to rise above domestic inflation. In addition, the optimal policy has the central bank accommodate real shocks that move the equilibrium terms of trade, also causing the cpi to vary relative to the domestic price index.

With commitment possible, the optimal policy is history dependent, as stressed by Woodford (1999), CGG and others. Following CGG, in this case, the optimal policy has the change in the output gap adjust to deviations of inflation from target:

$$
\mathrm{x}_{\mathrm{t}}-\mathrm{x}_{\mathrm{t}-1}=-\frac{\lambda_{w}}{\alpha_{w}} \pi_{\mathrm{t}}
$$

Roughly speaking, the "difference" rule exploits the dependence of current behavior on expectations of future policy. Equation (21) implies

$$
\mathrm{x}_{\mathrm{t}}=-\frac{\lambda_{w}}{\alpha_{w}} \mathrm{p}_{\mathrm{t}}
$$


which suggests that the policy is interpretable as domestic price level targeting. It remains optimal, however, to accommodate movements in the terms of trade. Even with commitment, accordingly, pegging the nominal exchange rate does not produce the best policy. 


\section{REFERENCES}

Aoki, Kosuki., "Optimal Monetary Policy Response to Relative Price Changes," mimeo, Princeton University, 1999.

Benigno, Gianluca and Benigno, Pierpaolo, "Price Stability as a Nash Equilibrium in Monetary Open Economy Models," mimeo, N.Y.U., 2000.

Calvo, Guillermo, "Staggered Prices in a Utility Maximizing Framework," Journal of Monetary Economics, 1983, 383-98.

Clarida, Richard, Jordi Gali. and Mark Gertler, "The Science of Monetary Policy: A New Keynesian Perspective,” Journal of Economic Literature, December 1999,

Corsetti, Giancarlo. and Paolo Pesenti, "Welfare and Macroeconomic Interdependence," forthcoming, Quarterly Journal of Economics.

Gali, Jordi and Tomasso Monacelli, “Optimal Monetary Policy and Exchange Rate Volatility in a Small Open Economy,” mimeo, Pompeu-Fabra , May 2000.

Obstfeld, Maurice and Kenneth Rogoff, "New Perspectives on Open Economy Modeling," Journal of International Economics , (50) February 2000, pp. 117-153.

Svensson, Lars, “Open Economy Inflation Targeting,” Journal of International Economics, (50) February 2000, pp. 155-183.

Woodford, Michael, “Optimal Monetary Policy Inertia,” NBER Working Paper No. 7261, 1999. 
* Columbia University, Universitat Pompeu Fabra, and New York University, respectively. We thank Pierpaolo Benigno, Frank Smets, and Lars Svensson for helpful discussions. 